\title{
Inner-City Children's Graphics Call for Social Justice
}

\author{
Lucia Y. Lu \\ Valdosta State University \\ 1500 N Patterson St. Valdosta, GA 31698, USA \\ E-mail: 1ylu@valdosta.edu
}

\begin{abstract}
In a graduate literacy course, the author as the teacher educator conceptualized "Visual Literacy" into the course. In-service and pre-service teachers from inner-city schools in Georgia and Virginia invited struggling writers to create graphic novels by envisioning life activities, using drawings, and invented spellings as well as conventional words to tell their family stories. This paradigm shift from a print-based curriculum to multimodal transmediation opened an alternate pathway to literacy, and the children became enthusiastically engaged. Their graphic novels vivified their life experiences, alleviated their pent-up emotions, and made their struggles visible and their inner voices audible. "Visual Literacy" enabled them to transcend the hardships that confronted them and ushered them into academic success.
\end{abstract}

Keywords: Envision, Multimode, Transmediation, Visual literacy, Graphic novel, Critical literacy

1. Introduction

"Eve presented her artifact (See Figure 1) sobbing,

'Nobody taught me how to write a story.

I never thought I could write a story like this.

I have many stories to tell you!

I can write as many stories as I like!

I will keep writing and drawing."”

One teacher from an inner-city school in Virginia shared Eve's reflections on graphic writing (all names are pseudonyms).

\subsection{Statement of Problem}

In a graduate literacy course, twelve teachers from the inner-city schools in Virginia were concerned that most of their middle grade students were reluctant to write. These children ranked two or three levels below the Virginia SOL in reading, writing and basic math, and were not able to write simple sentences. The teachers predicted that those children would become future dropouts from school when I shared with them an article entitled "Dropout Nation" (Thornburgh, 2006) which reported that more than one-third of America's high school students left school without graduating.

\subsection{Objective}

The author and the teachers conceptualize "Visual Literacy" into writing, shift the paradigm of writing from print-based curriculum to multimodal transmediation, open an alternate pathway to literacy, and engage the struggling learners in the inquiry of authentic writing toward school success.

\section{What is "Visual Literacy"?}

\subsection{Definition of Visual Literacy}

The term "Visual Literacy" was first coined by John Debes (1969), co-founder of International Visual Literacy Association (IVLA), who tentatively defined "Visual Literacy" as a group of vision-competencies that a human being can develop by seeing and simultaneously integrating other sensory experiences, and the development of these competencies is fundamental to normal human learning (International Visual Literacy Association, 2010).

For John Dewey (1934), art is the visual form of experience that vivifies life. Langer (1957) extends it, and argues that works of art are projections or images of feeling, present feeling, and make it visible or audible or perceivable through a symbol.

Pett (1988) claimed that communicating with visual images is an ancient yet natural concept; for instance, the early people used cave drawings to record and express thoughts, feelings, and events in their lives.

\subsection{Visual Literacy is Semiotics}

Semiotics is the study of signs (Sebeok, 1978; 2001). Language, art, music, dance, drama, mathematics, cultural modes, etc. are all signs that humans created to mediate the world (Cunningham, 1992; Deely, 1994). Vygotsky (1934) proclaimed that we need words and other signs to direct our mental operation. According to semiotics, a good language arts curriculum must be able to expand learner potential for understanding and communicating 
through a variety of signs, not only language (Hubbard, 1989; Leland \& Harste, 1994; Short, Kauffman, \& Kahn, 2000; Suhor, 1992).

\subsection{Multiple Forms of Literacy}

Visual arts and literacy are intrinsically linked (Flinders, 2005). In story strand, learners experiment in multiple ways by producing and interpreting stories. Through inquiry strand, learners focus on process strategies to form ideas with images (Piazza, 1999). Visual communication is one form of "new literacy" of the $21^{\text {st }}$ century for it is nearly impossible to think and not 'envision' (Rosenblatt, 1978), and educators have become cognizant of the fact that visual learning is central to communication (Cornett, 2007).

2.4 Art Contributes to Mental Health and Develops Creative Thinking

Art functions as "therapeutic" in education, for it provides opportunities for children to alleviate their pent-up emotions, which cannot be expressed by conventional words. Art also develops creative thinking since it has been one of the primary goals of education (Eisner, 1972).

2.5 Integrating Visual Arts into Literacy Education

In literacy education, Johnson (2008) asserts that "visual literacy" expands students' ability to "read" images contained in visual communication, and to "create" visual images for

communication. Most parents are more concerned with "verbal literacy" - the ability to read words rather than "visual literacy" - the ability to create messages by drawing, failing to observe that most children write using pictures before using conventional words (Beaty \& Pratt, 2008).

The arts are a symbolic partner with literacy education (Caughlan, 2008). All of the arts - visual arts, theater, music, dance, creative writing - are representations of human and natural worlds. Visual arts can be integrated into literacy education as writing prompts.

\subsection{Visual Literacy Opens an Alternative Pathway to Literacy}

Traditional conceptions of print-based literacy do not apprehend the complexity of actual literacy practices in human life (Mahiri, 2006). Children often use pictures as a natural language to communicate a message without any help from adults (Beaty \& Pratt, 2011). Harste, Woodward, \& Burke (1984) thus shifted adult conventions to children inventions by bringing a semiotic perspective to the study of young children's literacy learning.

\section{Holistic View of Language, Thinking and Learning}

Language is one of the sign systems that humans create to mediate the world (Cunningham, 1992; Deely, 1994). Vygotsky (1962) and Bruner (1966) believe that language is a major part of children's experience with the world, and only through the use of language can children learn to think abstractly. Thinking competence grows through the use of language in writing.

3.1 Critical Literacy

Kabuto (2008) defines Critical literacy as the process allowing children the right to choose among different modes and means of expression through multiple written languages and sign systems. We may see the complexity of literacy through decoding, encoding, transaction with children's life experiences, pragmatics and critical views (Burke \& Harste, 2008). In this study, we employed these processes into the 3-5 grade classrooms. The multimodal transmediation opens a door for the struggling learners to tell their life experiences in a very fluent and unaffected way. Consequently, school, family, and community activities emerge through this kind of "silent" inquiry. As teacher educators and classroom teachers, we may take an inquiry stance through critical literacy in our classroom, giving an ear to our students, and implementing curriculum that is authentic and meaningful to the children (MacGillivray \& Rueda, 2004).

\subsection{Writing is a Thinking Process}

When Goodman, Watson, \& Burke (2005) took a holistic view of language, thinking and learners, they assumed that (1) reading is an active, meaning-making process, (2) reading is a language process, and (3) readers have knowledge about language and their world. Based on this assumption, and the author's and teachers' observation of their students' writing behaviors, we all consent that writing, as well as reading, is also a thinking process.

Insert Graph 1 Here

\section{Visual Literacy in Action}

\subsection{Participants}

4.1.1. Adults

The in-service and pre-service teachers in the inner-city schools in Virginia and Georgia.

4.1.2 Students

Middle grade students in the inner-city schools in Virginia and Georgia, who are two or three levels below Virginia SOL and GA GPS in reading, writing, and basic math. Most students were either from the families of low income, or single parent dependent upon welfare.

4.2 Visual Literacy Ushers an Alternative Pathway to Literacy 
In this study, we conceptualized "visual literacy" into the writing inquiry. The in-service and pre-service teachers perpetually assured their timid students that their writings were not the graded assignments and that they were free to use words and pictures as equal signs for writing (Olshansky, 2006). This announcement released students from writing anxiety, and they eagerly engaged. "Visual Literacy" guided the struggling learners onto an alternate pathway to literacy (Bitz, 2004), and converted the reluctant writers to enthusiastic authors.

4.3 Multisensory Functions in Process Writing

Most of the children in the inner-city were far below the standards of VA SOL and GA GPS in reading, writing and the basic math. To convince the children that they could write well, we included multisensory action in writing. The teachers read aloud with the class the following "tips" for writing (Chapman and King, 2003; Lu, 2005):

If I can see it, I can think it,

If I can think it, I can say it,

If I can say it, I can write it,

If I can write it, I can read it. (p. 8)

In the beginning of the new semester, the teachers asked students to bring their family photos to class. Before writing, each student displayed the photo(s), drew 4-6 panels of pictures to describe the story based on the photo(s), and shared their pictures. For students who were embarrassed to bring family photos, we encouraged them to think about their family activities, envision these activities, and draw 4-6 panels. Later, the teachers invited each child to write one sentence, by invented spellings or conventional words, below each panel of drawing. For the children who spoke English as a second language or the children who struggled in writing, we advised them to dictate their family stories to their teachers.

\subsection{Build a Therapeutic Classroom with Trust and Respect}

Most children were very shy in sharing their feelings or family stories. To motivate children to write about their family stories or feelings, we all agreed to build a therapeutic classroom with trust and respect (Cramer, 2001). The teachers told the students that their writings were not counted as graded and that all student artifacts were graciously accepted. These simple strategies worked very well, and the children were enthusiastically in response.

\subsection{Spelling is Part of Writing}

Savage (2007) asserted that spelling is a part of writing. Spelling involves the visual representation of spoken sounds by written symbols and is part of learning. As a component of functional writing, spelling is part of children's engagement in written language, especially within the context of process writing.

4.5.1 Invented Spelling in Use

The encoding process of phonics and phonemic awareness are integrated in this study. Since spelling is part of writing, the children were encouraged to "sound it out" (Savage, 2007) and "write it down" before and when they asked teachers for help. Laminack \& Wood (1996) declared that children must be given authority, or power, over words, a power that allows them to say what they want to, just as they would in speech.

\section{Findings}

Safety and health issues are rarely discussed problems. This lack decreases children's chances for success (MacGillivray \& Rueda, 2004). The following seven graphic novels created by Eve, Sarah, Adam, Rebecca, Abraham, Jacob and Joseph (all names are pseudonyms) revealed the hidden problems that seriously impacted the inner-city children's success in academia.

\subsection{Poverty \& Drugs}

Figure 1 is entitled "Mom is in jail because of the NSF checks and hard drugs". It illustrates that Eve and her family were struggling in poverty, and as a result, her mother was forced to use NSF checks to purchase necessities in the grocery store, and eventually turned to hard drugs, leading to incarceration.

\subsection{Disease \& Child Abuse}

Figure 2 is entitled "The baby toddled down the street when her mom was sick on bed". Sarah was reminded by her aunt who adopted her after her mother died, that Sarah, the baby girl, opened the door and toddled down the street when she was only 18 months old.

\subsection{Environmental Hazards- Bee Sting}

Figure 3, entitled "Boys got lost in woods and got bee sting" depicts Adam and other boys living in a shelter house, going out to play, getting lost in the woods, and stepping on the bee hives. The children recounted stories displaying the environmental hazards in their neighborhood.

5.4 A Broken Family

Figure 4, entitled "A broken family," records the scene of Rebecca and her family going to the state fair. Her parents argued all the way home, and finally, the father left and did not come back. She living in a broken family filled with fear and anxiety. 


\subsection{Violence and Crime}

Figure 5, entitled "We met bullies at trick or treat" shows Abraham and several other boys encounters with bullies on Halloween.

\subsection{Starvation}

Figure 6, entitled "I love cook!" displays the fact that this 8-year old boy Jacob always suffered from starvation, his mother worked hard and came home very late. Jacob planned to be a chef, cooking eggs for himself and his young sisters. He used eight panels of graphics to describe how to cook eggs.

\subsection{Mommy is Leaving for Iraq}

Figure 7, entitled, "Momma is leaving for Iraq" was written by a 10 year old boy Joseph, who was in fifth grade, but whose reading was on a second grade level. Joseph's graphic novel was about his Mom being deployed to Iraq. The following was his dedication to his teacher, Ms. Trower:

The first picture "Momma getting ready to go" showed him at home with his Mom, Grandma and younger brother (age 5), getting ready for her to leave, with her duffle bag and her uniform. In this picture the student made his Mom the focus in that she was larger than anyone or anything else in the room.

The second picture "Bye Momma" showed the day of leaving with all the soldiers. Joseph and his Mom said goodbye. This was the saddest picture because you can see how much Joseph loves his mom when he surrounded her picture with hearts. The third picture "Fighting for the USA" showed his mom and other soldiers in a desert and had tanks in it. He wrote underneath it, "Fighting for the USA!"The fourth picture, "Welcome Home Momma" in which he expected his momma returns six months later, He and his brother hugging their Mom. The student wrote, "Welcome Home Momma" as his sentence.

The last picture, "This was the best day!" The trip to Disney is fun because his Mom is there and so are his Aunts, Uncles and cousins. He wanted to stay forever because he knew he would miss his Mom a lot!

Ms. Trower described her observation of his writing:

When writing the graphic novel you could see a big difference in the student between completing a reading task and drawing. The student was the most focused that I have seen and enjoyed creating a picture of when his Mom comes home. The student misses his Mom a lot and says that he can't wait for her to be back so he can say goodnight to her in person. The student once he moved on to writing captions to label his pictures with, he seemed more willing to complete the task. In observing the graphic novel task, I believe that this helped the student in creating a piece of writing that connected to the picture.

\section{Discussion}

\subsection{Writing is Therapy}

When read the children's graphic novels, we felt vicariously the children's emotions of sorrows, anxiety, fears, worries, conflicts, concerns, frustration, etc. Both Eisner (1972) and Cramer (2001) claim that writing is a form of therapy. Contemporary psychologists and psychiatrists use expressive writing as a therapeutic medium (Cramer, 2001) and an outlet of releasing the strong emotions children experience. Oral language serves the immediate need for emotional release, but written language is permanent, and it can be examined, extended, revisited and serves as an ideal medium for expressing thoughts and feelings. Writing gives writers and their audience access to the concerns and burdens that children might otherwise bear alone. Carry (2010), a researcher of urban literacy education, made the similar discovery that all urban children had voices that could be developed effectively through writing (Scott, \& Teale, 2010).

\subsection{Writing Calls for Social Justice}

6.2.1 What is Social Justice?

Social justice governs how social institutions deal fairly with the needs of people, compromising on what is good for individuals and groups (Freire, 1993). It also secures social rights and benefits in terms of such provisions of well-being such as nutrition, housing, employment, education, and health care (Lum, 2007). The goal is to confront discrimination, oppression, and institutional inequities, and to build an ideal condition in which all members of a society have the same basic rights, protection, opportunities, obligations, and social benefits (Soest, 2007)

6.3 Education for Social Justice

When young children are exposed to the situations, not of their own will, they should be provided with an opportunity to channel their thoughts and feelings in positive and creative ways through speaking or writing (Short \& Kauffman, 2008). They may absorb some of the socially upheld ethics and morals and make the world a better place to live. As teacher educators and classroom teachers, we all must have the capacity and passion for implementing new literacy across the curriculum by encouraging the struggling learners use multimodal transformations to express social injustices and call for social justice from their authentic artifacts. 


\subsubsection{Fertile Grounds for Creativity}

Standards, assessment and relentless accountability wield limited creativity and imagination in the classroom. Sturgell (2008) claims that classroom should be grounds where teachers are free to sow with passion and understanding and plant the seeds of creativity and imagination.

6.3.2 Intellectual Freedom

As teacher educator and classroom teachers, we are supposed to support the idea of intellectual freedom and the rights of students (Kabuto, 2008; Schliesman, 2008). In this study, the struggling learners were allowed to use the media, like drawings and invented spellings with which they have become familiar, to tell their stories.

\section{Educational Applications and Significance}

\subsection{Inner-City Children are At-Risk}

The author and the in-service or pre-service teachers felt that these inner-city children were at-risk. Most lived in privations with single striving parents, or homeless, if social action was not taken immediately, their problems would soon surpass low scores in reading, writing or basic math in the future.

\subsection{Differentiated Instruction in Writing}

\subsubsection{Why Differentiated Instruction}

Based on the research of Chapman \& King (2003), children's diversity can be examined by ability, behavior, experience, gender, intelligences, interest, learning styles, language proficiency, socioeconomic status, physical appearance, cultural background, family support, etc. In the inclusive classrooms in inner-city, differentiated instruction may meet their diverse needs.

\subsubsection{Implementation of Differentiated Instruction in Literacy Education}

In teacher education, the author as the teacher educator requires her students who are the in-service or pre-service teachers to complete a Differentiated Instruction Project every semester. Each one works with one struggling learner in his/her own classroom or in Practicum by (1) using the survey in www.internet4classrooms./di.htm to figure out the child's strength and weakness, (2) observing the child's learning behavior in reading and writing, (3) interviewing the child for his/her feelings about reading and writing, (4) inviting the child to create a graphic novel to tell his/her family story, and (4) offering intervention strategies to help the child develop his/her thinking, reading, speaking and writing. This assignment provides the in-service and pre-service teachers opportunities to obtain insight into individual student's learning and plan more effective instruction.

\subsubsection{Language Experience Approach for Modeling Writing}

The English language learners and the students who are struggling with conventional writing, are encouraged to dictate to their teachers after drawing. Based on Language Experience Approach (Ashton-Warner, 1965), teachers or adults may use this approach to model (Fisher, Frey, \& Lapp, 2009) the writing process when taking dictation of children's storytelling and facilitate speech-to-print connections for children (Fisher, Brozo, Frey \& Ivey, 2007;). This activity also serves as a record of children's thinking as they learn. Children are enthusiastically engaged in the thinking-drawing-sharing-writing-reading processes. Since some inner-city students come to school tired, hungry, and in sullen moods, and having nothing to think about but their misfortune, the author modified this approach by inviting the children to bring family photos to class and share the photos before drawing. Children experienced the cycle of semiotic transformation starting from photos to thinking, to storytelling, to drawing, to writing and finally back to reading.

The language the children used in this research was just what they used out-of-school settings (Jacob, 2008) at home, or the playground, and in the community. This activity provided children choices to write for a variety of authentic purposes, helping them make connections between their lives inside and outside of school. The struggling learners, engaged in this literacy activity, found that the language in their writing is consistent with their languages at home, or the playground and in their neighborhood. They should be able to experience authentic and powerful uses of language within communities that are meaningful to them (Ryan, 2008).

\subsection{Learning to Speak: Learning to Spell}

The stages of spelling development can be found throughout the inner-city children's artifacts like phonetic spelling, transitional spelling, and conventional spelling. We observed how the struggling learners made progress from invented spellings to conventional words. Invented spelling should be recognized as a series of important phases that children go through as they learn to write. Invented spelling reflects a developmental process, a way of helping young children become effective writers. Children's invented spelling is based on their knowledge of phonics. Invented spelling requires the knowledge of phonics and reflects an attempt to apply logic and strategies to producing written communication. It represents a useful vehicle for teaching phonics as part of learning to write, and provides interesting ways for teachers to assess and diagnose what children already know about 
letter-sound relationships, and their developing knowledge of the orthographic system (Savage, 2007) and linguistic cuing system (Goodman, Watson, \& Burke, 2005).

7.3.1 Spelling is an extension of children's language development

Laminack \& Wood (1996) also declared that spelling is an extension of children's language development with the following four principles of children's spelling:

1) Spelling is evaluated on the basis of natural writing rather than tests

2) Spelling is evaluated analytically rather than as merely right or wrong

3) Spelling is looked at in terms of children's strategies rather than in isolation

4) The teacher should evaluate spelling as an informed professional rather than as a mechanical test scorer. (P.

37)

\section{Conclusion}

The inquiry of "Visual Literacy" in this study shifted the paradigm of writing from print-based instruction to multimodal transmediation, forged an alternative pathway to literacy, and the inner-city children were eager to engage. Their graphic novels vivified their life experiences, alleviated their pent-up emotions, and made their struggles visible and their inner voices audible. Classroom activities based on "Visual Literacy" and other semiotic forms like arts, music, dance, drama, etc. in education expand learner's potential for understanding and communicating through a variety of sign or sign systems, and usher the inner-city children into school success.

\section{References}

Ashton-Warner, S. (1965). Teacher. New York: Simon \& Schuster.

Beaty, J. J. \& Pratt, L. (2011). Early literacy in preschool and kindergarten: A multicultural perspective. ( $3^{\text {rd }}$ ed.). New York: Pearson Education Inc.

Bitz, M. (2004). The comic book project: Forging alternative pathways to literacy. Journal of Adolescent \& Adult Literacy 47:7. 574-586.

Burke, C. \& Harste, J. (2008). Profiles and perspectives. Language Arts, 86(2). 120-126.

Caughlan, S. (2008). Advocating for the arts in an age of multiliteracies. Language Arts. 86(2). 120-126.

Chapman, C. \& King, R. (2003). Differentiated instructional strategies for reading in the content areas. Thousand Oaks, CA: Corwin Press, Inc.

Cornett, C. E. (2007). Creating meaning through literature and the arts: An integration resource for classroom teachers $\left(3^{\text {rd }}\right.$ ed.). Upper Saddle River, NJ: Pearson Merrill Prentice Hall.

Cramer, D. (2001). Creative power: The nature and nurture of children's writing. New York: Addison Wesley Longman, Inc.

Cunningham, D. J. (1992). Beyond educational psychology: Steps toward an educational semiotic. Educational Psychology Review, 4, 165-194.

Debes, J. (1969) What is visual literacy? International Visual Literacy Association. http://en.wikipedia.org/wiki/Visual_literacy 8 April 2010.

Deely, J. (1994). The human use of signs. London: Rowman \& Littlefield Publishers, Inc.

Dewey, J. (1934). Art as experience. New York: Minton, Balch, and Company.

Eisner, E. W. (1972). Educating artistic vision. New York: The Macmillan Company.

Fisher, D., Brozo, W. G., Frey, N. \& Ivey, G. (2007). 50 content area strategies for adolescent literacy. Upper Saddle River, NJ: Pearson Merrill Prentice Hall.

Fisher, D., Frey, N. \& Lapp, D. (2009). In a reading state of mind: Brain research, teacher modeling, and comprehension instruction. Newark, DE: International Reading Association.

Flinders, D. (2005). Multiple worlds, multiple ways of knowing: Elliot Eisner's contributions to educational research. In P. Bruce Uhrmacher. \& Jonathan Matthews. Intricate palette: Working the ideas of Elliot Eisner. Upper Saddle River, NJ: Pearson Education, Inc.

Freire, P. (1993). Education for critical consciousness. New York: The Continuum Publishing Company.

Goodman, Y. M., Watson, D. J. \& C. L. Burke (2005). Reading miscue inventory: From evaluation to instruction $\left(2^{\text {nd }}\right.$ ed.). New York: Richard C. Own Publishers, Inc.

Harste, J. C., Short, K. G. \& Burke, C. (1988). Creating classrooms for authors. Portsmouth, NH: Heinemann.

Hassett, D. D. \& Curwood, J. S. (2010). Theories and practices of multimodal education: The dynamics of picture and primary classroom. The Reading Teacher, 63(4). 270-282.

Jacob, G. (2008). We learn what we do: Developing a repertoire of writing practices in an Instant Messaging world. Journal of Adolescent \& Adult Literacy. 52(3). 203-211. 
Johnson, M. H. (2008). Developing verbal and visual literacy through experience in the visual arts. Young Children, 63(1). 74-77.

Kabuto, B. (2008). Using children's literature to teach for social justice: Critical literacy and language rights. In C. S. Rhondes, L. B. Wolf, \& J, Darvin (Eds.). From contemplation to Action: Promoting social justice through children's literature (pp. 89-103). Scottsdale, AZ: Holcomb Hathaway, Publishers.

Laminack, L. L. \& Wood, K. (1996). Spelling in use. Urbana. IL: National Council of Teachers of English.

Langer, S. K. (1957). Problems of art. New York: Charles Scribner's Sons.

Leland, C. H. \& Harste, J. C. (1994). Multiple ways of knowing: Curriculum in a new key. Language Arts, 71(5), 337-345.

Leland, C. H., Harste, J. C. \& Huber, K. R. (2005). Out of the box; Critical literacy. Language Arts, 82(4). 257-267.

Lum, D. (2007). (Ed.). Culturally competent practice: A framework for understanding diverse groups and justice issues ( $3^{\text {rd }}$ ed.). Australia: Thomson Brooks/Cole.

MacGillivray, L. \& Reuda, R. (2004). Listening to inner city teachers of English language learners: Differentiating literacy education. In R. D. Robinson, McKenna, M. C., \& Wedman, J. M. Issues and trends in literacy education ( $3^{\text {rd }}$ ed.).(pp. 96-102). New York: Pearson Education, Inc.

Mahiri J. (2006). Digital dj-ing: Rhythms of learning in an urban school. Language Arts, 84(1), 55-62.

McIver, C. J. (2007). Comic strips as a text structure for learning to read. The Reading Teacher, 61(1). 85-88.

Moll, L. C. (1997). Introduction. In L. C. Moll (Ed.). Vygotsky and education. (pp. 1-27). New York, NY: Cambridge University Press.

Olshansky, B. (2006). Artists/writers workshop: Focusing on the art of writing. Language Arts, 83(6). 533-536.

Pett, D. (1988). One person's perspective. History of the International Visual Literacy Association.

Piazza, C. L. (1999). Multiple forms of literacy: Teaching literacy and the arts. Upper Saddle River, NJ: Merrill Prentice Hall, Inc.

Ray, K. W. (1999). Wondrous words: Writers and writing in the elementary classroom. Urbana, IL: NCTE.

Rosenblatt, L. M. (1978). The reader, the text, the poem: The transactional theory of the literary work. Carbondale, IL: Southern Illinois University Press. (2008). Engaging middle years students: Literacy projects that matter. Journal of Adolescent \& Adult Literacy, 52(3), 190-201.

Savage, J. F. (2007). Sound it out! Phonics in a comprehensive reading program ( ${ }^{\text {rd }}$ ed.). Boston: McGraw-Hill.

Schliesman, M. (2008). Intellectual freedom. Language Arts, 85(3). 221-226.

Scott, J. L. \& Teale, W. H. in collaboration with Carry, D.D., Johnson, N., \& Morgan, D. R. (2010). Effective literacy instruction for urban children: Voices from the classroom. The Reading Teacher, 63(4). 338-341.

Sebeok, T.A. (1978). Sight, sound and sense. Bloomington, IN: Indiana University Press.

Sebeok, T.A. (2001). Global semiotics. Bloomington, IN: Indiana University Press.

Short, K. G., Harste, J. C. \& Burke, C. (1995). Creating classrooms for authors and inquirers. ( $2^{\text {nd }}$ ed.). Portsmouth, NH: Heinemann.

Short, K. G., Kauffman, G. \& Kahn, L. H. (2000). "I just need to draw": Responding to literature across multiple sign systems. The Reading Teacher, 54 (2), 160-171.

Siegel, M. (2006). Rereading the signs: Multimodal transformations in the field of literacy education. Language Arts, 84(1), 65-77.

Soest, D. V. (2007). Advancing social and economic justice. In D. Lum. Culturally competent practice: A framework for understanding diverse groups and justice issues ( $3^{\text {rd }}$ ed.). Australia: Thomson Brooks/Cole.

Sturgell, I. (2008). Touchstone texts: Fertile ground for creativity. The Reading Teacher, 61(5). 411-414.

Suhor, C. (1992). Semiotics and the English language arts. Language Arts, 69, 228-230.

Thornburgh, N. (2006). Dropout Nation. Time. 167(16). 30-40.

Vygotsky, L. (1934/1986). Thought and language (Newly revised and edited by Alex Kozulin). Cambridge, MA: The MIT Press. 


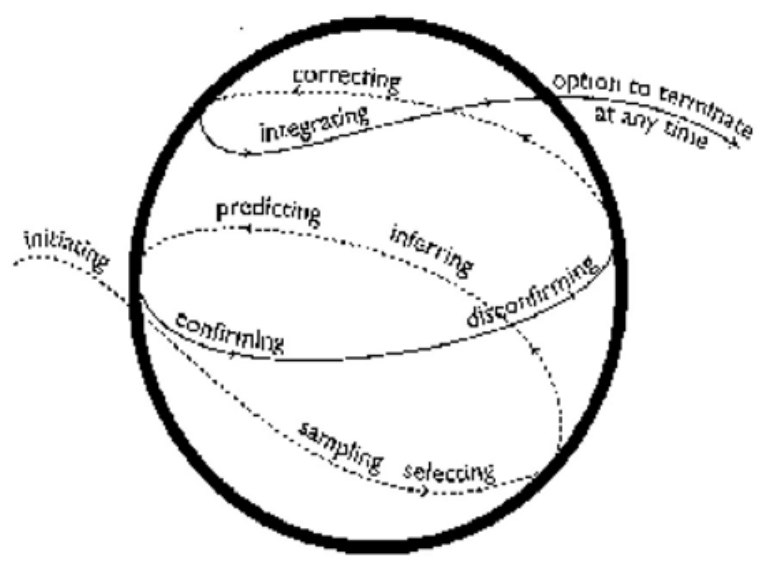

Graph 1. A Holistic View of Literacy (Goodman, Watson, \& Burke, 2005)
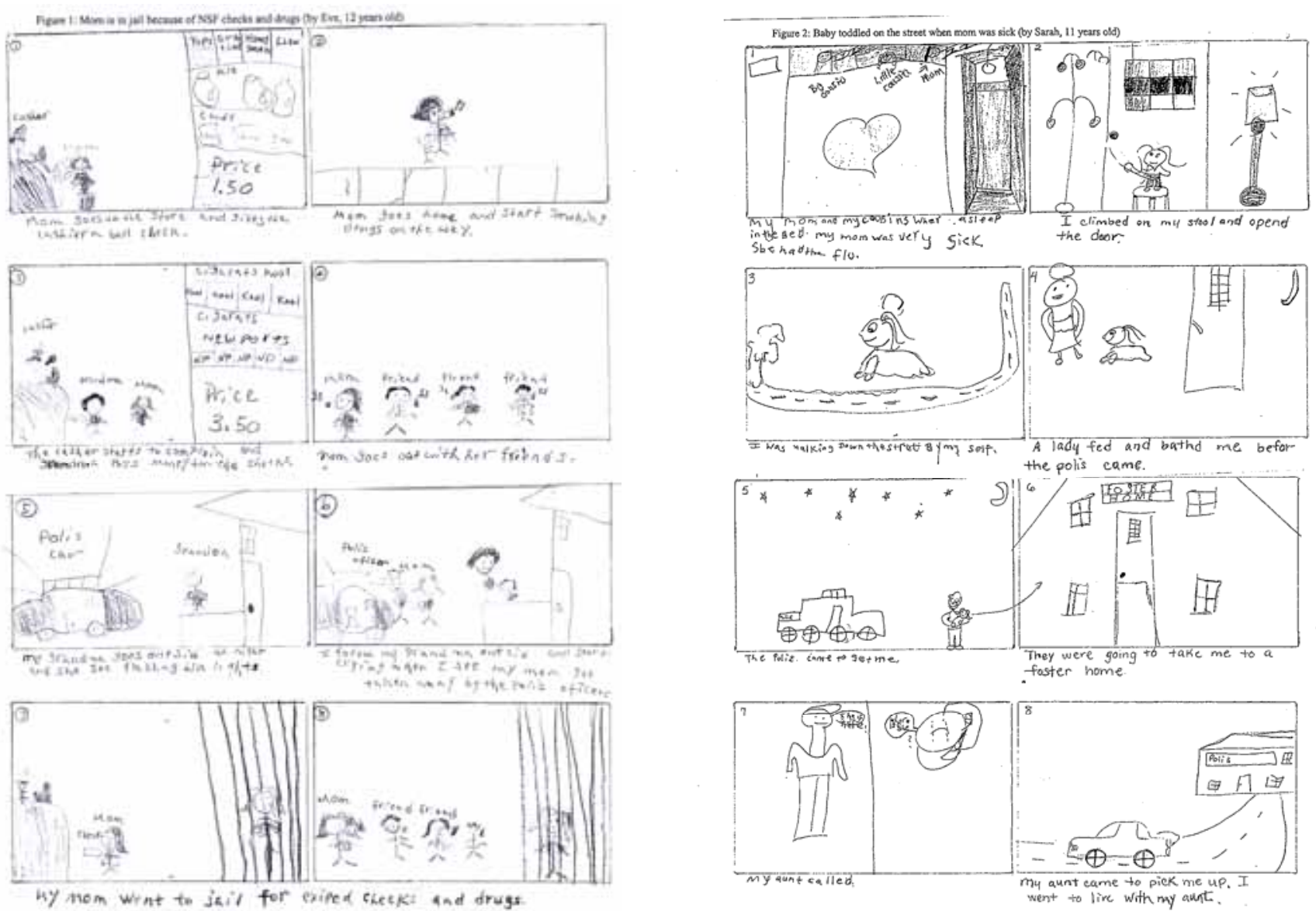

Figure 1. Mom is in jail because of NSF checks and drugs (by Eve, 12 years old)

Figure 2. Baby toddled on the street when mom was sick (by Sarah, 11 years old) 

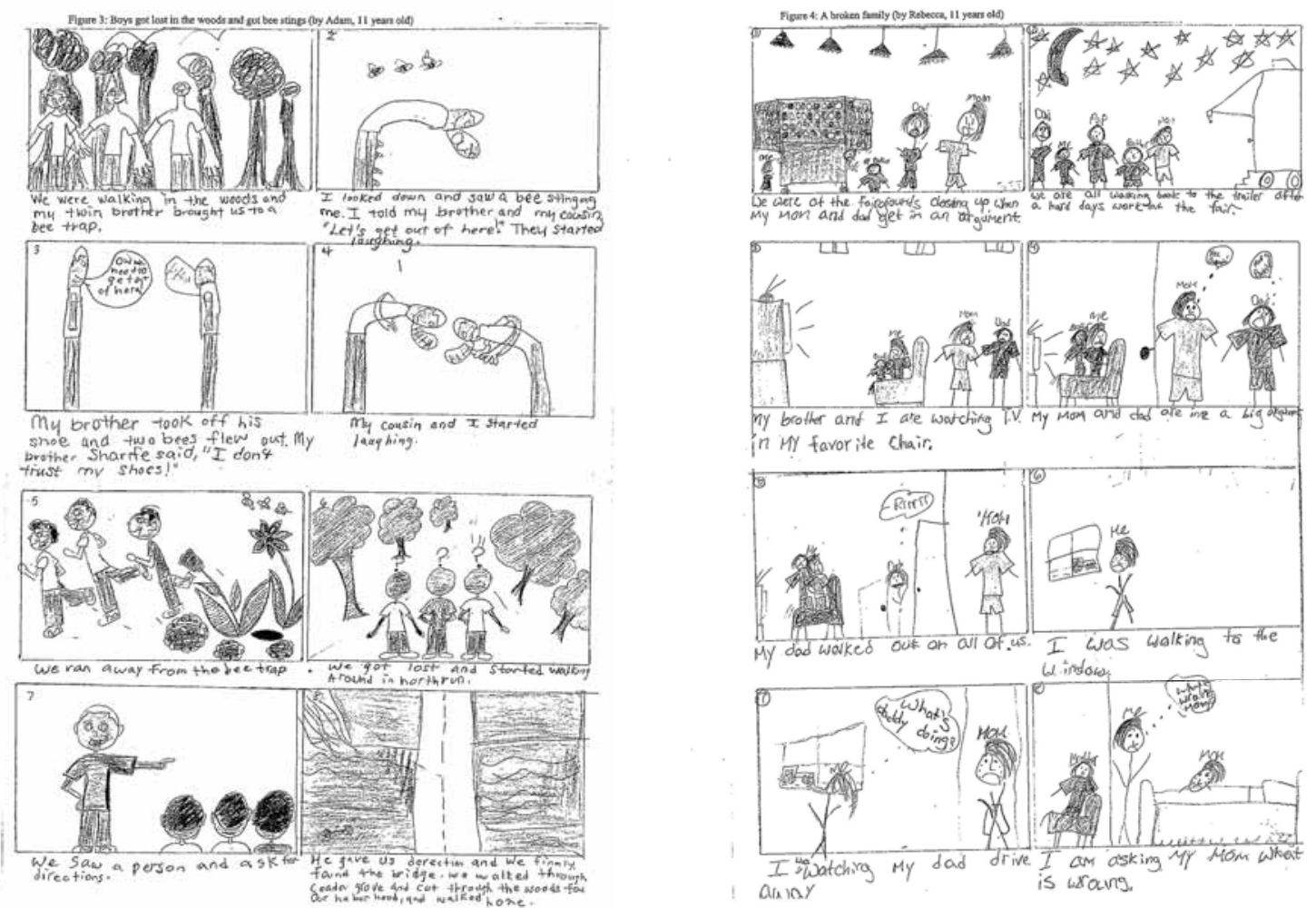

Figure 3. Boys got lost in the woods and got bee stings (by Adam, 11 years old)

Figure 4. A broken family
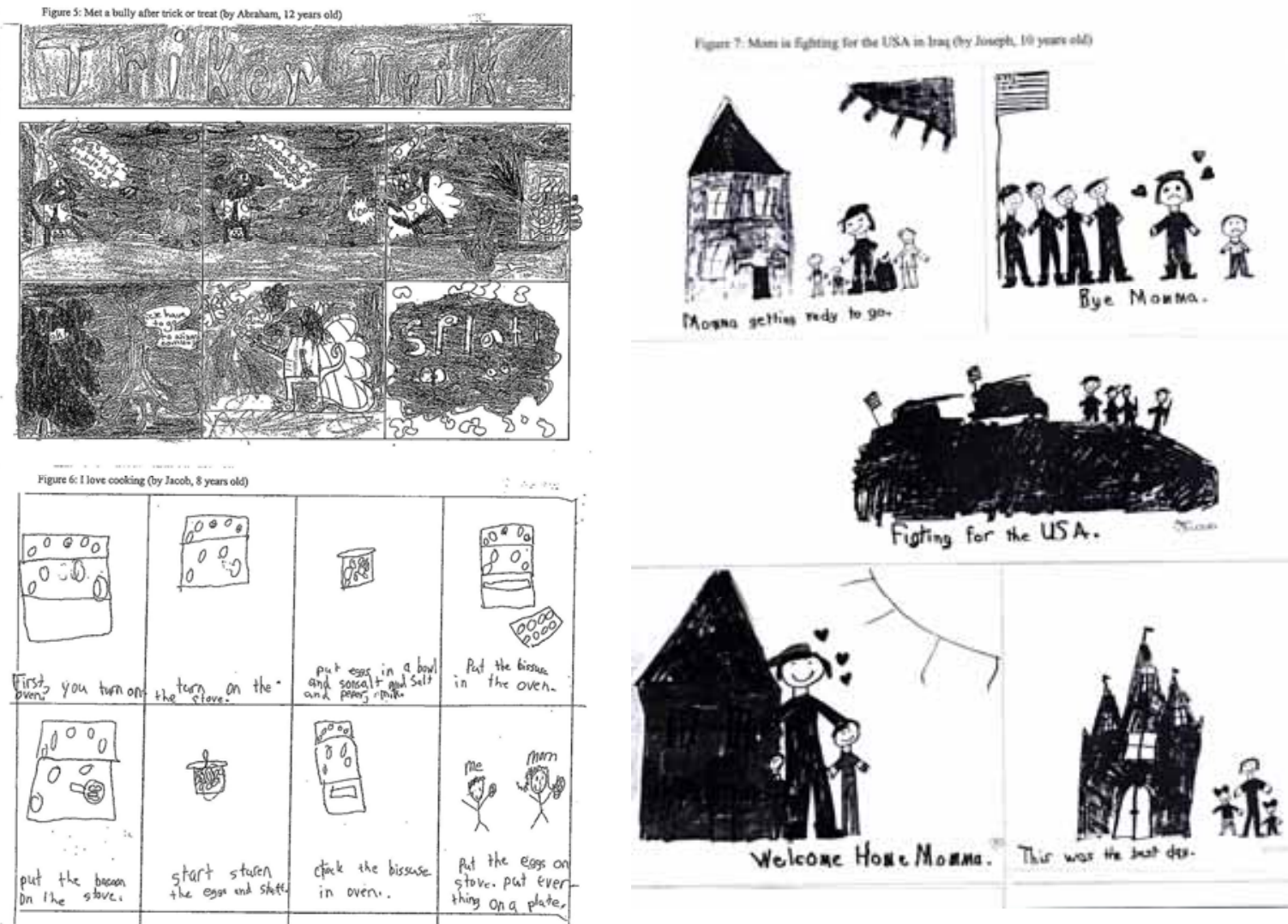

Figure 5. Met a bully after trick or treat (by Abraham, 12 years old)

Figure 6. I love cooking (by Jacob, 8 years old)

Figure 7. Mom is fighting for the USA in Iraq (by Joseph, 10 years old) 